\title{
BORON RATES FOR TRITICALE AND WHEAT CROPS
}

\author{
Juliano Corulli Corrêa ${ }^{1}$; José Antônio de Fátima Esteves ${ }^{1}$; Helio Grassi Filho ${ }^{2 *}$; Elza Alves ${ }^{1}$; \\ Gessi Ceccon ${ }^{3}$ \\ ${ }^{1}$ UNESP/FCA - Programa de Pós-Graduação em Agricultura. \\ ${ }^{2}$ UNESP/FCA - Depto. de Recursos Naturais/Ciência do Solo, C.P. 237 - 18603-970 Botucatu, SP - Brasil. \\ ${ }^{3}$ Embrapa Agropecuária Oeste - BR 163, km 253,6 - 79804-970 - Dourados, MS - Brasil. \\ *Corresponding author <heliograssi@fca.unesp.br>
}

\begin{abstract}
No reports are registered on responses to boron fertilization nutrient deficiency and toxicity in triticale crops. The aim of this study was to evaluate triticale response to different rates of boron in comparison to wheat in an hapludox with initial boron level at $0.08 \mathrm{mg} \mathrm{dm}^{-3} 4 \times 4$ factorial design trial completely randomized blocks design $(\mathrm{n}=4)$. Boron rates were $0 ; 0.62 ; 1.24$ and $1.86 \mathrm{mg} \mathrm{dm}^{-3}$; triticale cultivars were IAC 3, BR 4 and BR 53 and IAPAR 38 wheat crop was used for comparison. The wheat (IAPAR 38) crop presented the highest boron absorption level of all. Among triticale cultivars, the most responsive was IAC 53, presenting similar characteristics to wheat, followed by BR 4; these two crops are considered tolerant to higher boron rates in soil. Regarding to BR 53, no absorption effect was observed, and the cultivars was sensitive to boron toxicity. Absorption responses differed for each genotype. That makes it possible to choose and use the best-adapted plants to soils with different boron rates.
\end{abstract}

Key words: Triticosecale, Triticum aestivum, absorption

\section{NÍVEIS DE BORO EM CULTIVARES DE TRITICALE E TRIGO}

\begin{abstract}
RESUMO: No Brasil não existem registros de respostas de adubação com boro para a cultura do triticale, sendo a ação deste nutriente uma incógnita, tanto em relação a deficiência quanto a toxidez, causas que levam a redução de produtividade. O objetivo deste trabalho foi avaliar a resposta do triticale a diferentes níveis de boro em comparação com o trigo (Triticum aestivum). Utilizou-se um Latossolo Vermelho distrófico com teor inicial de boro de $0,08 \mathrm{mg} \mathrm{dm}^{-3}$. O delineamento foi um fatorial $4 \times 4$, distribuído em blocos casualizados, com quatro repetições, quatro níveis de boro: 0; 0,62; 1,24 e 1,86 $\mathrm{mg} \mathrm{dm}^{-3}$ de B e três cultivares de triticale, IAC 3, BR 4 e BR 53, mais um cultivar de trigo, IAPAR 38, para comparação. Cada cultivar respondeu de forma diferente com relação às variáveis estudadas em função da aplicação de diferentes níveis de boro. $\mathrm{O}$ trigo (IAPAR 38) apresenta maior eficiência na absorção de boro. A cultivar de triticale mais responsiva quanto à absorção foi a IAC 3, que apresentou característica semelhante ao trigo, seguida da cultivar BR 4, demonstrando serem cultivares tolerantes a maiores níveis de boro no solo. Para a BR 53, não ocorreu efeito para absorção, com a cultivar apresentando sensibilidade à toxidez de boro. A eficiência de absorção é diferenciada para cada genótipo possibilitando a escolha e utilização de plantas que possuam maior adaptação ao meio.
\end{abstract}

Palavras-chave: Triticosecale, Triticum aestivum, absorção

\section{INTRODUCTION}

Production of triticale (X. Triticosecale WITTMACK), a hybrid of wheat and barley, has been expanding in several parts of the world. In Brazil, it is used as alternate species for winter crop and as a sowing option concomitant to wheat, because of its tolerance to acid soil; therefore, it contributes to higher productivity averages than wheat (Baier, 1986; 1995; Felício et al., 1993; 2001).

Studies related to soil fertility management for triticale crop have been limited to macro nutrients; liming and fertilization, boron fertilization in triticale culture is done according to studies and responses for wheat. The action of boron in triticale crops regarding nutrient deficiency and toxicity, which may cause productivity decreases, is still unknown.

Several factors in the soil affect boron availability: $\mathrm{pH}$, texture, humidity and temperature (Gupta, 2002). Wheat crop response mechanisms to boron depend on the cultivar and there are different responses to fertilization (Mahboodi et al., 2002, Torun et al., 2001, Hu \& Brown, 1997). Each crop group also presents different genetic capability, which can be more less or responsive to fertilization as a result of active and passive mechanisms of boron absorption (Dordas \& Brown, 2001) and the capability of stopping Alcoholsugar-B complex through phloem (Bellaloui et al., 2003); these processes make the crop more adaptable to the environment. 
The aim of this study was to evaluate the rates of boron in the soil for different triticale crops compared to a wheat crop.

\section{MATERIAL AND METHODS}

This experiment was carried out in a greenhouse, Botucatu-SP. The soil was a medium-textured dystrophic Haplodux, collected dried in the arable layer, sieved (2 mm), and analyzed according to Raij et al. (2001). The soil presented the following chemical characteristics: $\mathrm{pH}\left(\mathrm{CaCl}_{2}\right)=4.0$; M.O. $=20 \mathrm{~g} \mathrm{dm}^{-3} ; \mathrm{P}_{\text {resin }}=2 \mathrm{mg} \mathrm{dm}^{-3}$; $\mathrm{H}+\mathrm{Al}=64 \mathrm{mmol}_{\mathrm{c}} \mathrm{dm}^{-3} ; \mathrm{K}=0.2 \mathrm{mmol}_{\mathrm{c}} \mathrm{dm}^{-3} ; \mathrm{Ca}=2$ mmol $_{\mathrm{c}} \mathrm{dm}^{-3} ; \mathrm{Mg}=1 \mathrm{mmol}_{\mathrm{c}} \mathrm{dm}^{-3} ; \mathrm{SB}=3 \mathrm{mmol}_{\mathrm{c}} \mathrm{dm}^{-3}$; $\mathrm{CTC}=67 \mathrm{mmol} \mathrm{dm}_{c}^{-3} ; \mathrm{V}=4(\%) ; \mathrm{B}=0.08 \mathrm{mg} \mathrm{dm}^{-3}$, and $\mathrm{Zn}=0.4 \mathrm{mg} \mathrm{dm}^{-3}$, determining low fertility soil. Chemical analyses to determine rates of B and Zn were done using Hot Water Method and DTPA, respectively.

Liming was done to increase base saturation to $60 \%$ using dolomite limestone (relative neutralizing potential - RNP: 89\%); the soil was kept covered for 20 days. After that, sowing fertilization was done using 150 $\mathrm{mg} \mathrm{dm}^{-3}$ of $\mathrm{K}$ as $\mathrm{KCl}, 50 \mathrm{mg} \mathrm{dm}^{-3}$ of $\mathrm{N}$ as carbamide, 200 $\mathrm{mg} \mathrm{dm}{ }^{-3}$ of $\mathrm{P}$ as simple superphosphate, and $2 \mathrm{mg} \mathrm{dm}^{-3}$ of $\mathrm{Zn}$ as zinc sulphate. Fertilizers were all mixed in the soil of $10-\mathrm{L}$ pots, with 12 plants each. Five plants were removed in the booting stage for nutritional evaluation of the flag leaf; seven plants were kept up to the yield stage.

The characteristic soil water curve was determined using porous plates as recommended by Kiehl (1979). Pots were there weighed and values of soil water retention for the humidity management during the experiment were obtained from daily weighing and surface watering.

The experiment was carried out in a $4 \times 4$ factorial scheme randomized blocks design $(n=4)$. Treatments were determined by four rates of boron in the soil: $0,0.62$, 1.24 and $1.86 \mathrm{mg} \mathrm{dm}^{-3} \mathrm{~B}$ using boric acid, three triticale (X. Triticosecale WITTMACK) cultivars, IAC 3, BR 4 and BR 53, and IAPAR 38 wheat cultivar (Triticum aestivum L.). Wheat and triticale cultivars used in this study were chosen because of their productivity, tolerance to acidity and seed availability in São Paulo and Paraná states.

Production components were determined pooling all seven plants of each pot. The following components were evaluated: number of spikes, number of spikelets, number of grains, number of hollow grains, plant dry matter, and B concentration in the flag leaf (Malavolta et al., 1997).

The results were submitted to regression analysis, adjusting equations to data obtained for rates of boron and adopting interaction through significant $\mathrm{F}$ test $(\alpha=0.05)$ and determining coefficient magnitude as criteria for choosing a model. A variance analysis was carried out through $\mathrm{F}$ figures and using the average value of rates of boron for each cultivar.

\section{RESULTS AND DISCUSSION}

Boron rates affected studied variables, except plant dry matter (Table 1). Wheat genotypes may be efficient, normal and inefficient regarding boron absorption in similar conditions of nutrient concentration in the soil, and there are differed absorption mechanisms among the species (Jamjob \& Rerkasem, 1999).

BR 53 cultivar presented greater boron absorption capability, as demonstrated by concentration averages in flag leaf (Table 1), but had smaller number of spikes, spikelets and grains in comparison to the other crops; 34 $\mathrm{mg} \mathrm{kg}{ }^{-1} \mathrm{~B}$ may be considered harmful to these variables in this crop. Another explanation for the difference between yield components of BR 53 and the other crops is the genetic origin. IAC3 and BR 4 cultivars did not differ regarding boron concentration, but BR 4 was more responsive to boron application in to yield components.

Each crop responded differently to rates of boron, phenomenon also reported for wheat crops by Subedi et al. (1999), Torun et al. (2001), Mahboodi et al. (2002), and Fageria (2002) (Figure 1 and 2). These responses to boron are related to the kind of absorption each crop pre-

Table 1 - Average effect of boron rate among triticale and wheat crops for number of spikes, grains, hollow grains, spikelets, plant dry matter and boron concentration in flag leaf. Replication mean value for production components refer seven plants of the pots.

\begin{tabular}{|c|c|c|c|c|c|c|}
\hline Treatment & No. spikes & No. grains & No. hollow grains & No. spikelets & Plant dry matter & B concentration \\
\hline Crops & & & & & g plants ${ }^{-1}$ & $\mathrm{mg} \mathrm{kg}$ \\
\hline IAC 3 & $32 \mathrm{~B}$ & $610 \mathrm{AB}$ & $145 \mathrm{~B}$ & $762 \mathrm{~B}$ & 34 & $27 \mathrm{~B}$ \\
\hline BR 4 & $35 \mathrm{~A}$ & $672 \mathrm{~A}$ & $265 \mathrm{~A}$ & $945 \mathrm{~A}$ & 39 & $28 \mathrm{~B}$ \\
\hline BR 53 & $29 \mathrm{C}$ & $487 \mathrm{C}$ & $165 \mathrm{AB}$ & $647 \mathrm{C}$ & 37 & $34 \mathrm{~A}$ \\
\hline IAPAR 38 & $33 \mathrm{AB}$ & $602 \mathrm{~B}$ & $107 \mathrm{C}$ & $727 \mathrm{~B}$ & 40 & $30 \mathrm{AB}$ \\
\hline C.V. $(\%)$ & 8.9 & 6.8 & 15 & 9.1 & 4.2 & 3.0 \\
\hline
\end{tabular}

Averages followed by distinct letters differ in the D.M.S. Test at 5\% 
sents. Therefore absorption efficiency may be used to select genotypes best adapted to boron concentration in the soil (Jamjob \& Rerkasem, 1999).

Number of spikes and grains were similar and presented square effect for BR 4, IAPAR 38 and BR 53 cultivars (Figure 1). BR 4 presented the best number of spikes at $1.06 \mathrm{mg} \mathrm{dm}^{-3} \mathrm{~B}$, and number of grains, at $0.90 \mathrm{mg} \mathrm{dm}^{-3}$ B. IAPAR 38 presented the highest values for the same
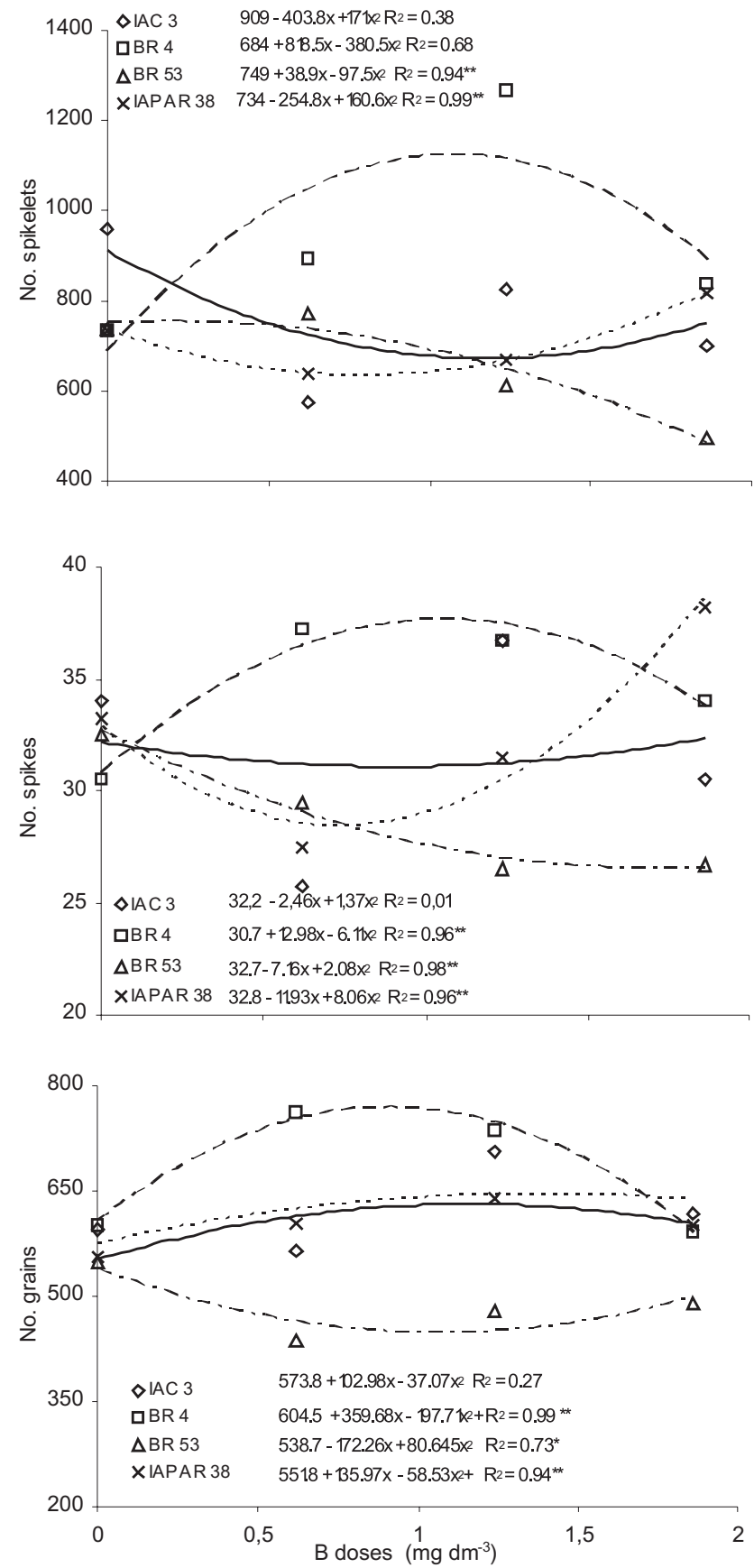

Figure 1 - Number of spikes, spikelets and grains in three triticale crops and one wheat crop for application of rates of boron. Replication mean value for production components refer to seven plants of pots. variables at $0.90 \mathrm{mg} \mathrm{dm}^{-3} \mathrm{~B}$. BR 35 was sensitive to boron toxicity for the same variables, and also sensitive to $0.2 \mathrm{mg} \mathrm{dm}^{-3} \mathrm{~B}$ for number of spikes and number of grains.

In wheat crops, boron toxicity accounts for 15$17 \%$ decrease in root and leaf tissues, by the increase of glutamate dehydrogenase action, that is activated by GDH in leaves. This activity increase is an adaptation mechanism of the species against boron stress.
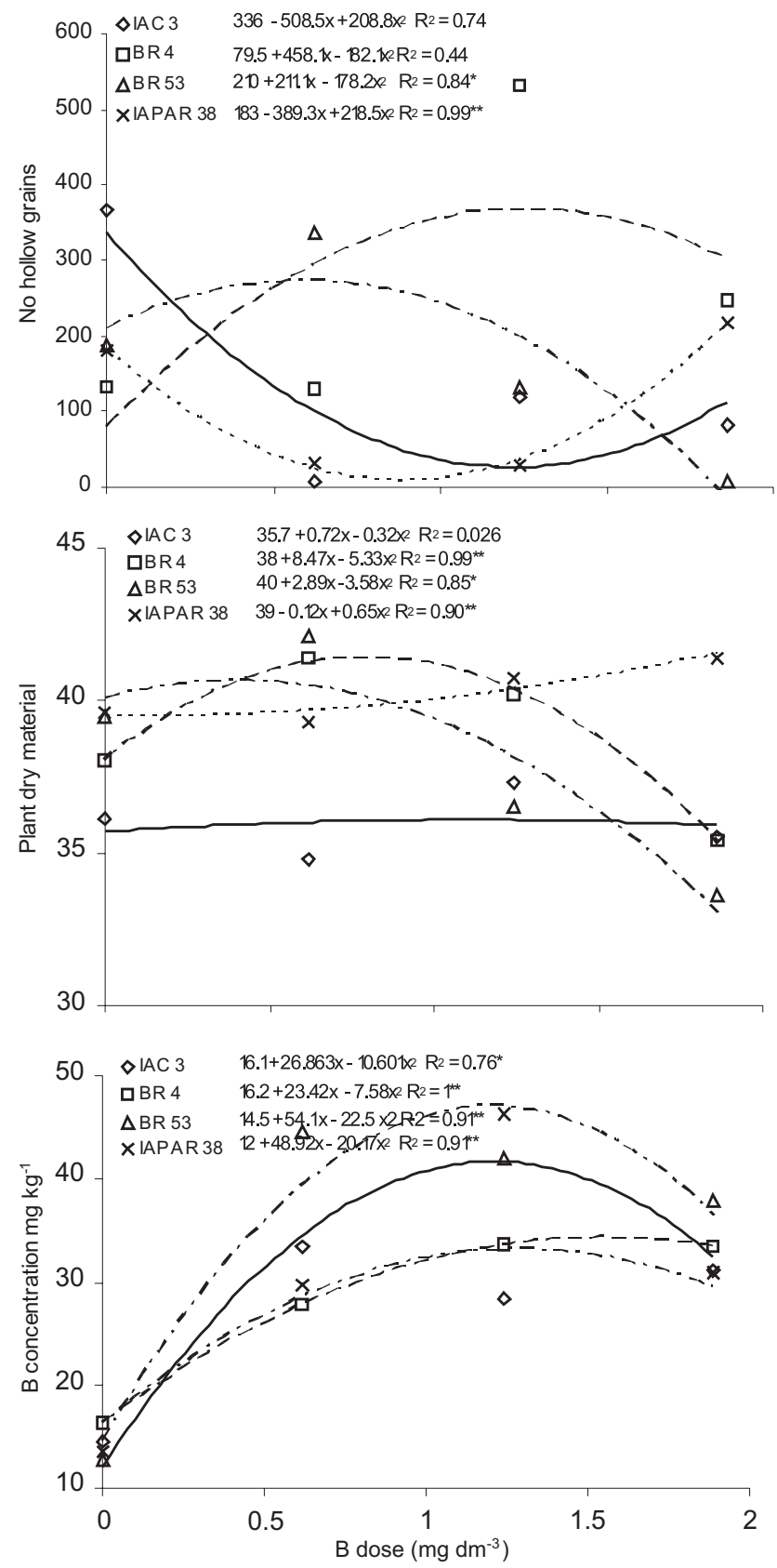

Figure 2 - Number of hollow grains, plant dry material and b concentration in flag leaf in three triticale crops and one wheat crop for application of rates of boron concentration. 
Effects on number of spikelets were significant only for BR 53 and IAPAR 38. An increasing effect occurred in BR 53, with highest results at $0.20 \mathrm{mg} \mathrm{dm}^{-3}$ $\mathrm{B}$; higher concentrations of boron reduced the number of spikelets. IAPAR 38 presented the highest number of spikelets at $0.79 \mathrm{mg} \mathrm{dm}^{-3} \mathrm{~B}$. The higher the number of spikelets, the higher the productivity. Therefore, IAPAR 38 can be considered the most responsive one to boron application, whereas BR 53 is sensitive to B toxicity. Plants that are better adapted to the environment are more likely to have higher productivity or, severe stress situations, such as the absence of micro nutrients, some adapted species can perform appropriately controlling boron absorption through a mechanism in the plasmatic membrane, which has different types and quantities of intrinsic proteins responsible for boron absorption through ion canals or bilipidic layer (Dordas \& Brown, 2001). There is a greatest transfer of boron from root to leaves in crops more tolerant to boron deficiency, when B supply is restricted by the environment (Subedi et al., 1999).

The number of hollow grains was significant for cultivars BR 53 and IAPAR 38 (Figure 2). There was an increasing effect for BR 53 up to $0.59 \mathrm{mg} \mathrm{dm}^{-3} \mathrm{~B}$, and a reduction in the number of hollow grains from there on. IAPAR 38 presented the lowest number of hollow grains up to $0.89 \mathrm{mg} \mathrm{dm}^{-3} \mathrm{~B}$, and an increase in the number of hollow grains from that rate up. Thus, IAPAR 38 is more responsive to boron application than BR 53, which is more sensitive to lower rates of boron in the soil.

Plant dry matter was significant for BR 4, BR 53 and IAPAR 38 in regression analysis; the highest values for dry matter were observed at rates $0.79 \mathrm{mg} \mathrm{dm}^{-3} \mathrm{~B}, 0.40$ $\mathrm{mg} \mathrm{dm}{ }^{-3} \mathrm{~B}$, and at the last level, respectively. IAPAR 38 shows greater response to increasing boron rates in the soil in comparison to triticale, and is more balanced in relation to dry matter production.

Boron concentration in flag leaf presented effect in square regression for IAC 3, BR 4 and IAPAR 38 the highest boron concentration in the leaf occurred at rates of $1.27,1.45$, and $1.21 \mathrm{mg} \mathrm{dm}^{-3} \mathrm{~B}$, respectively. Boron absorption ratio occurred at the following order: IAPAR $38>$ BR $4>$ IAC 3. Boron deficiency decrease leaf concentration and elicits smaller number of grains, spikes and spikelets, decreasing productivity; Boron concentration in the soil at $4 \mathrm{mg} \mathrm{kg}^{-1} \mathrm{~B}$ is considered the limit for low productivity in barley and wheat crops (Jamjob \& Rerkasem, 1999). Boron absorption among crops differ in similar soil concentration conditions, and several mechanisms are involved in regulation of boron absorption in different species (Hu \& Brown, 1997).

Appropriate boron fertilization rates for wheat provide better development and productivity (Subedi et al., 1999; Fageria, 2002; Asad \& Raquel, 2002). Wheat needs $0.6 \mathrm{mmol} \mathrm{L}^{-1}$ of boron solution to develop well, and lower concentration rates set up deficiency symptoms. The appropriate B concentration in wheat leaf is $1.2 \mathrm{mg}$ $\mathrm{kg}^{-1}$ of dry matter (Asad, 2002) and, regardless the crop, boron partition is different in the several organs: 68\% in leaves, $16 \%$ in roots, $10 \%$ in grains and $6 \%$ in stem (Subedi et al., 1999). The values for boron concentration in wheat observed herein at zero dose using the method described by Raij et al. (2001), and the highest value of 39.43, were obtained in $0.88 \mathrm{mg} \mathrm{dm}^{-3} \mathrm{~B}$; the highest values for plant dry matter (Figure 2) and the number of spikelets (Figure 1) were found close to this rate.

Transpiration is the mechanism that coordinates boron transportation in plants, mainly through xylem, from absorption by the roots to combination in younger leaves (Huang et al., 2001). Absorption mechanisms of plants suggest that there is active and passive B absorption; passive absorption occurs with the direct passage through the bilipidic membrane, as result of absence of boron, whereas active absorption happens through canals where these mechanisms are controlled by the boron concentration (Dordas \& Brown, 2001).

\section{REFERENCES}

ASAD, A. Boron requirement for sunflower and wheat. Journal of Plant Nutrition, v.25, p.885-899, 2002.

ASAD, A.; RAQUEL, R. Identification of micronutrient deficiency of wheat in the Peshawar Valley, Pakistan. Communications in Soil Science and Plant Analysis, v.33, p.349-364, 2002.

BAIER, A.C. Triticale. Passo Fundo, EMBRAPA, CNPT, 1986. 24p. (Documentos, 6).

BAIER, A.C. Potencial do triticale no Brasil. In: REUNIÃO BRASILEIRA DE TRITICALE, 4., Chapecó, 1992. Anais. Chapecó: EPAGRI, 1995. p.8-23.

BELLALOUI, N.; YADAVC, R.C.; CHERN, M.S.; HU, H.; GILLEN, A.M.; GREVE, C.; DANDEKAN, A.M.; RONALD, P.C.; BROWN, P.C. Transgenically enhanced sorbitol synthesis facilitates phloem-boron mobility in rice. Physiologia Plantarum, v.117, p.79-84, 2003.

DORDAS, C.; BROWN, P.H. Evidence mediated channel in transport of boric acid in Squash. Plant and Soil, v.235, p.95-103, 2001.

EMPRESA BRASILEIRA DE PESQUISA AGROPECUÁRIA. Sistema brasileiro de classificação de solos. Brasília: Embrapa Produção de Informação; Rio de Janeiro: Embrapa Solos, 1999. 412p.

FELICIO, J.C.; CAMARGO, C.E.O.; PIZZINATTO, A.; CASTRO, J.L.; GALLO, P.B. Comportamento agronômico e avaliação tecnológica de genótipos de triticale no estado de São Paulo em 1988 a 1989. Pesquisa Agropececuária Brasileira, v.28, p.281-294, 1993.

FELICIO, J.A.; CAMARGO, C.E.O.; FERREIRA FILHO, A.W.P.; GALLO, P.B. Avaliação de genótipos de Triticale e Trigo em ambientes favoráveis e desfavoráveis no estado de São Paulo. Bragantia, v.60, p.83-91, 2001.

FAGERIA, N.K. Micronutrients influence on root growth of upland rice, common bean, wheat, and soybean. Journal of Plant Nutrition, v.25, p.613-622, 2002.

GUPTA, U.C. Boron and its role in crop production. Boca Ratow: CRC Press, 2002. 237p.

HU, H.N.; BROWN, P.H. Absorption of boron by plant roots. Plant and Soil, v.193, p.49-58, 1997.

HUANG, L.B.; BELL, R.W.; DELL, B. Boron supply into wheat (Tritcum aestivum L. cv. Wilgoyne) ears whilst still enclosed within leaf sheaths. Journal of Experimental Botany, v.52, p.1731-1738, 2001.

JAMJOB, S.; RERKASEM, B. Genotypic variation in response of barley to boron deficiency. Plant and Soil, v.215, p.65-72, 1999.

KIEHL J.C. Manual de edafologia: relação solo planta. São Paulo: Ceres, 1979. 246p. 
MAHABOODI, H.; YUCEL M.; OKTEM, H.A. Nitrate redutase and glutamate dehydrogenase activities of resistant and sensitive cultivars of wheat and barley under boron toxicity. Journal of Plant Nutrition, v.25, p.1829-1837, 2002.

MALAVOLTA, E.; VITTI, G.C.; OLIVEIRA, S.A. Avaliação do estado nutricional das plantas: princípios e aplicações. 2.ed. Piracicaba: Associação Brasileira para a Pesquisa da Potassa e o Fosfato, 1997. 319p.

RAIJ, B. van; ANDRADE, J.C.; CANTARELLA, H.; QUAGGIO, J.A. Análise química para avaliação da fertilidade de solos tropicais. Campinas: Instituto Agronômico de Campinas, 2001. 285p.
SUBEDI, K.D.; GREGORY, P.J.; GOODING, M.J. Boron accumulation and partitioning in wheat cultivars with contrasting tolerance to boron deficiency. Plant and Soil, v.214, p.141-152, 1999.

TORUN, A.; GULTEKIN, I.; KALAYEI, M.; YLMAZ, A.; ELKER, S.; CAKMAK, I. Effects of zinc fertilization on grain yield and shoot concentrations of zinc, boron, on phosphorus of 25 wheat cultivars grown on a zinc deficient and boron toxic soil. Journal of Plant Nutrition, v.24, p.1817-1829, 2001.

Received November 28, 2003

Accepted December 17, 2004 